\title{
Effect of Kepok Banana Peel Extract (Musa spp.) on the Number of Pituitary Basophil Cells in Rats (Rattus norvegicus) with High-Fat Diet
}

\author{
Nora Usrina ${ }^{1}$, Muslim Akmal ${ }^{2,}$, Rinidar Rinidar ${ }^{3}$, Mustafa Sabri ${ }^{4}$, and Gholib Gholib ${ }^{5}$ \\ ${ }^{1}$ Veterinary Public Health Master Program, Faculty of Veterinary Medicine of Universitas Syiah Kuala, Darussalam Banda Aceh, \\ 23111 Indonesia \\ ${ }^{2}$ Laboratory of Histology, Faculty of Veterinary Medicine of Universitas Syiah Kuala, Darussalam Banda Aceh, 23111 Indonesia \\ ${ }^{3}$ Laboratory of Pharmacology, Faculty of Veterinary Medicine of Universitas Syiah Kuala, Darussalam Banda Aceh, 23111 Indonesia \\ ${ }^{4}$ Laboratory of Anatomy, Faculty of Veterinary Medicine of Universitas Syiah Kuala, Darussalam Banda Aceh, 23111 Indonesia \\ ${ }^{5}$ Laboratory of Physiology, Faculty of Veterinary Medicine of Universitas Syiah Kuala, Darussalam Banda Aceh, 23111 Indonesia
}

\begin{abstract}
Banana peels are the outer envelopes of banana fruits as the by-product of household consumption and banana processing. Kepok banana peel contains bioactive compounds that function as antioxidants which reduce the effects of free radicals. This research was conducted to determine the effect of giving Kepok banana peel extract on the number of basophilic cells in rats with a high-fat diet. The study used 25 male rats aged 2.5-3 months old, which alloted into 5 groups with 5 rats each. The first group was fed on standard feed (K1, positive control), while the second group given high-fat diet (K2, negative control). The rats in group 3, 4, and 5 were given high-fat diet + vitamin C (K3), high-fat diet $+100 \mathrm{mg} / \mathrm{kg} \mathrm{BW}$ banana peel extract (K4), and high-fat diet $+200 \mathrm{mg} / \mathrm{kg} \mathrm{BW}$ banana peel extract (K5), respectively. A sample of the pituitary gland was collected after 60 days of the treatment. The data were analyzed using one way analysis of variance (ANOVA) followed by the Duncan test. The results of this study indicated that the administration of Kepok banana peel extract at a dose of $100 \mathrm{mg} / \mathrm{kg}$ BW can maintain the number of basophilic cells, whereas at dose of $200 \mathrm{mg} / \mathrm{kg} \mathrm{BB}$ has the potential to reduce the number of basophilic cells in rats fed high-fat feed.
\end{abstract}

Keywords: kepok banana peel, FSH, antioxidants.

\section{Introduction}

Bananas are one of the national fruits with a wide distribution area. In Indonesia, banana production reached 5.8 million tons in 2010 with an economic value of $\operatorname{Rp} 6.5$ trillion [1]. Kepok bananas are included in the types of bananas that can be consumed raw or after being processed. Banana peels are the outer envelopes of banana fruits as the by-product of household consumption and banana processing [2,3]. Kepok banana peels contain bioactive compounds that function as antioxidants, such as tannins, saponins, and flavonoids [4,5]. Andini [5] further stated that the content of flavonoids and phenols in bananas can reduce the concentration of cholesterol, free fatty acids, and triglycerides in serum and tissue.

The excessive high-fat feed can lead to obesity which in turn will affect the dysregulation of reproductive function. Dysregulation occurs on the hypothalamicpituitary-testis axis [6]. The basophilic cell is one of the cells that can be disrupted in form and function. According to Yang et al. [6], a high-fat diet can affect basophil cells in producing their hormones. Basophilic cells are one type of cells found in the pituitary.
Basophilic cells are known as endocrine cells which produce many hormones, one of which is reproductive hormones [7].

Many studies have been developed to look at the antioxidant effects of plants which can inhibit the negative effects of a high-fat diet. However, the effect of the active compound of Kepok banana peel extract on the number of pituitary basophil cells in male rats on a high-fat diet has not been conducted. Therefore, the present study was carried out to determine the effect of giving Kepok banana peel extract on the number of basophilic cells in rats with a high-fat diet.

\section{Materials and Methods}

This study used 25 adult male rats (Rattus norvegicus) aged 2.5-3 months and body weight ranged from 160-180 grams. The sample used in this study was rat pituitary. All methods used in the study have been approved by the Ethical Committee of Experimental Animals of Veterinary Faculty of Universitas Syiah Kuala No. 25/KEPH/III/2019. 


\subsection{Animal Treatments}

Before treatment, the rats were adapted for 7 days and had free access to given water and feed, then they were randomly divided into five treatment groups. The rats in: positive control group (K1) were given standard feed, while those in negative control group (K2) were given high-fat diet. The rats in treatment groups (K3, K4, and K5 ) were given high-fat diet + vitamin C at dose of 100 $\mathrm{mg} /$ day; high-fat diet + kepok banana peel extract at a dose of $100 \mathrm{mg} / \mathrm{kg} \mathrm{BW}$; high-fat diet + kepok banana peel extract at a dose of $200 \mathrm{mg} / \mathrm{kg} \mathrm{BW}$, respectively The high diet used in this study was modified from Selamet et al. (2013). High-fat diet in the treatment contained $1.5 \%$ egg yolk (15 g cholesterol/1 $\mathrm{kg}$ standard feed), $10 \%$ beef fat (100 $\mathrm{g}$ cholesterol $/ 1 \mathrm{~kg}$ standard feed), $1 \%$ coconut oil (10 $\mathrm{g}$ cholesterol $/ 1 \mathrm{~kg}$ standard feed) and $1 \%$ butter (10 g cholesterol $/ 1 \mathrm{~kg}$ standard feed). The treatment was carried out for 60 days and the feed given was $6 \mathrm{mg} /$ day.

\subsection{Lee index calculation in rat}

Lee index in rats was calculated based on the ratio between the cube root of body weight $(\mathrm{g})$ and nasoanal length $(\mathrm{cm})$ of rats [9]. The Lee index was calculated every week during the treatment. According to Malafaia et al. (2013), the normal Lee index value for the rat is less than 0.30 .,

\subsection{Histopathological preparations}

The hypophysis glands of Rats in each treatment group were collected by surgery. The surgery was initiated with the euthanization process of rats using ketamine xylazin intramuscularly. To isolate the pituitary gland, the upper skin of the os cranium was dissected, and then the os cranium was cut using scissors. The brain was lifted to expose the pituitary gland then isolated from the duramater. The isolated pituitary gland was then washed using a $0.95 \%$ physiological $\mathrm{NaCl}$ solution and then put in a $4 \%$ paraformaldehyde fixation solution for 24 hours. The preparation of histopathological sample referred to the Kiernan method (1993). The pituitary organ that had been fixed for 24 hours was put into the basket tissue and labeled. Then the pituitary tissue sample was dehydrated with a series of ethanol concentration from $70 \% 1,80 \%$, $90 \%, 95 \%$, and absolute ethanol I, II, III for two hours each.

After the dehydration process, a cleansing process is carried out by inserting tissue into xylol three times each for one hour. Then the infiltration process was carried out in liquid paraffin three times each for one hour. The next stage was the embedding process in paraffin. The pituitary tissue blockwas cut using a $5 \mu \mathrm{m}$ microtome and placed on an object-glass that has been coated with an adhesive. The tissue that has been affixed to the glass object was then stained with Mayer's Hematoxylin-eosin and subsequently observed. The cells observed and counted were basophilic cells whose cytoplasm absorbs alkaline colors (purple) as seen in Figure 1. The number of basophilic cells wass then counted from 5 sides of the field of view.

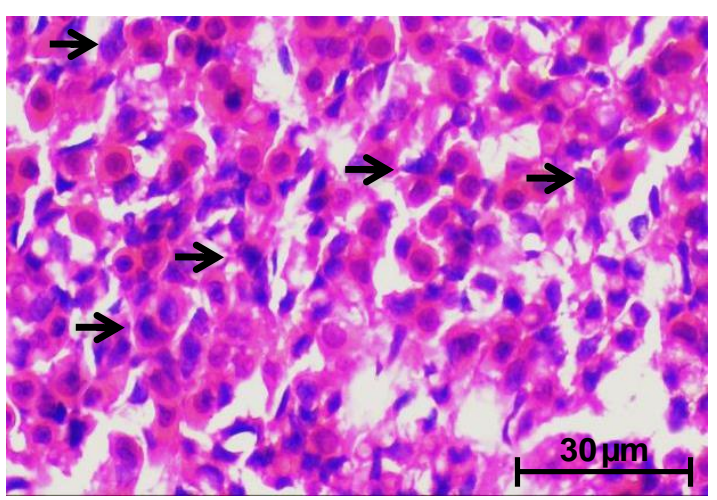

Figure 1. Basophilic cells in pars distalis adenohypophysis (arrows) in rats

\subsection{Data analysis}

The data were analzed using one way ANOVA.

\section{Results and Discussion}

\subsection{Lee's Index of Rats}

The Lee Index is one of the parameters that can be used in estimating body composition in rats [9]. In this study, the Lee index calculation was presented based on the ratio between cube roots of body weight $(\mathrm{g})$ and nasoanal length $(\mathrm{cm})$ of rats. The Lee index calculation results are presented in Table 1.

Table 1. Lee's index of rat in each group (every week)

\begin{tabular}{cccccc}
\multirow{2}{*}{ Week } & \multicolumn{5}{c}{ Lee Index (Mean \pm SE) } \\
\cline { 2 - 6 } & $\mathrm{K} 1$ & $\mathrm{~K} 2$ & $\mathrm{~K} 3$ & $\mathrm{~K} 4$ & $\mathrm{~K} 5$ \\
\hline 1 & $0,33 \pm 0,00$ & $0,33 \pm 0,01$ & $0,33 \pm 0,00$ & $0,33 \pm 0,01$ & $0,33 \pm 0,01$ \\
2 & $0,33 \pm 0,00$ & $0,33 \pm 0,01$ & $0,33 \pm 0,00$ & $0,33 \pm 0,00$ & $0,33 \pm 0,01$ \\
3 & $0,33 \pm 0,00$ & $0,33 \pm 0,01$ & $0,33 \pm 0,00$ & $0,33 \pm 0,01$ & $0,33 \pm 0,01$ \\
4 & $0,32 \pm 0,01$ & $0,33 \pm 0,01$ & $0,33 \pm 0,01$ & $0,33 \pm 0,00$ & $0,33 \pm 0,01$ \\
5 & $0,32 \pm 0,01$ & $0,33 \pm 0,01$ & $0,32 \pm 0,01$ & $0,33 \pm 0,01$ & $0,33 \pm 0,01$ \\
6 & $0,32 \pm 0,01$ & $0,33 \pm 0,01$ & $0,32 \pm 0,00$ & $0,32 \pm 0,01$ & $0,32 \pm 0,01$ \\
7 & $0,32 \pm 0,00$ & $0,33 \pm 0,01$ & $0,32 \pm 0,01$ & $0,32 \pm 0,01$ & $0,32 \pm 0,01$ \\
8 & $0,32 \pm 0,00$ & $0,33 \pm 0,01$ & $0,32 \pm 0,01$ & $0,32 \pm 0,00$ & $0,32 \pm 0,01$ \\
\hline
\end{tabular}

Based on Table 1, the Lee index value in all groups of rats showed the number exceeds the normal limit of the Lee index rat. According to Malafaia et al. (2013), the normal Lee index value for the rat is less than 0.30 . The Lee index value can be used as a threshold for increasing weight in rat associated with obesity.

\subsection{The number of basophils cells in the rat pituitary gland}

The rat pituitary gland is divided into anterior lobes (adenohypophysis) and posterior lobes (neurohypophysis). Adenohypophysis is divided into pars distalis (PD) and pars intermedia (PI), whereas neurohypophysis only consists of pars nervosa (PN). In this study the distribution of basophil cells observed was pars distalis adenohypophysis. 
In the pituitary, anterior lobe or adenohypophysis is the largest part. In mammals and humans, this lobe is approximately almost $70 \%$ of the total weight of the gland. Jistologically, adenohyphophysis consists of glandular epithelial cells of various sizes and shapes and separated by capillaries. The pituitary with HE staining is divided into three types of cells, namely: (1) chromophobic cells, (2) chromatin cells that take on acidic (acidophil) colors such as prolactin-producing cells, and (3) chromatin cells that take on basic colors (basophils). LH and FSH-producing cells include endocrine cells that are basophilic and are called basophil cells [11].

The function of basophilic cell is to secrete the gonadotropin hormone such as FSH. T FSH hormone is a glycoprotein hormone produced by adenohypophysis gonadotropic cells that contain GnRH receptors. The results of the analysis of basophil cell distribution in pars distalis adenohypophysis are presented in Table 2.

Table 2. Distribution of basophil cells in the rat pituitary given of kepok banana peel extract

\begin{tabular}{cc} 
Groups & $\begin{array}{c}\text { Basophil } \\
(\text { mean } \pm \text { SE) }\end{array}$ \\
\hline K1 & $18,12 \pm 0,64^{\mathrm{a}}$ \\
K2 & $17,68 \pm 0,38^{\mathrm{b}}$ \\
K3 & $17,36 \pm 0,32^{\mathrm{b}}$ \\
K4 & $17,96 \pm 0,43^{\mathrm{a}}$ \\
K5 & $13,44 \pm 0,26^{\mathrm{c}}$
\end{tabular}

${ }^{\mathrm{a}, \mathrm{b}}$, cdifferent superscripts within the same colomn indicated the significant difference $(\mathrm{P}<0.05)$

Table 2 showed that the mean distribution of basophilic cells in the hypophysis of negative control group (K2) was smaller than that of the positive control (K1) even though there were no statistically significant differences. Giving vitamin $\mathrm{C}$ in the $\mathrm{K} 3$ treatment showed a significant decrease in the number of basophilic cells compared to K1 ( $\mathrm{P}<0.05)$, but not significantly different (P> 0.05) when compared to the $\mathrm{K} 2$ treatment. The distribution of basophilic cells increased when given with Kepok banana peel extract $100 \mathrm{mg} / \mathrm{Kg} \mathrm{BW}$ in the $\mathrm{K} 4$ treatment compared to the $\mathrm{K} 2$ negative control and statistically similar to the positive control (K1) .

This result proved that the administration of Kepok banana peel extract at a dose of $100 \mathrm{mg} / \mathrm{kg} \mathrm{BW}$ has antioxidant potential, therefore the basophilic cell distribution reach the normal distribution as the positive control. Conversely, there was a noticeable difference in $\mathrm{K} 5$ groups compared with the treatments of $\mathrm{K} 1, \mathrm{~K} 2, \mathrm{~K} 3$, and K4. The mean distribution of basophilic cells in the K5 treatment was smaller over the other treatments. This result indicated that the administration of Kepok banana peel extract at a dose of $200 \mathrm{mg} / \mathrm{kg} \mathrm{BW}$ tends to reduce the number of basophilic cell distribution in the pituitary gland.

Basophile cell activity in producing hormones will be dysregulated in obese mice [12]. This is caused by an increase in body fat levels followed by an increase in the production of reactive oxygen species (ROS) and lipid peroxidation [13]. According to Iswara (2009), antioxidants are needed by the body in neutralizing the effects of ROS and preventing damage caused by it.
Antioxidant potential in Kepok banana peel can be used to stabilize excess ROS production which affects reducing the number of basophil cells in the pituitary.

The ability of banana peels to stabilize excess ROS production which is influenced by excess fat content is associated with the antioxidant activity contained therein. Kepok banana peels contain bioactive compounds such as tannins, saponins, and flavonoids which act as antioxidants and can reduce levels of fat and cholesterol [14]. Tannins contained in the skin of Kepok bananas can increase the accumulation of cAMP stimulation in rat adipocytes that provide lipolytic effects. Tannins also play a role in reducing cholesterol in obese rats by inhibiting the enzyme HMG Co-A reductase which plays a role in cholesterol biosynthesis so that cholesterol absorption can decrease [15]. Flavonoids and saponins can improve plasma lipid profiles, reduce triglycerides and fatty acids, lower LDL cholesterol and slightly increase HDL cholesterol. Flavonoids are also able to reduce food intake through the appetite control pathway by leptin [16,17]. According to Bast and Haenen (2013), the use of natural ingredients as antioxidants must ensure the maximum limit of the dose used to be able to optimize therapy using antioxidants. In this regard, the reduction in the number of basophilic cells in K5 treatment which observed in this study (Table 2) was allegedly due to the use of excessive dose of kepok banana peel,interferes the absorption process of fat components needed by the body in certain amounts. According to Berawi and Bimandama (2018), the administration of Kepok banana peel extract at a dose of $8.4 \mathrm{mg}$ /day can reduce total cholesterol levels in the normal range, while at dose of $16.8 \mathrm{mg} /$ day can reduce total cholesterol below normal range. In this case, cholesterol is one of the important components in cell membranes.

\section{Conclusion}

Based on the results, it can be concluded that the administration of Kepok banana peel extract at a dose of $100 \mathrm{mg} / \mathrm{kg}$ BW can maintain the number of pituitary basophilic cells in rats with a high-fat diet, while at dose of $200 \mathrm{mg} / \mathrm{kg} \mathrm{BB}$ has the potential to reduce the number of basophilic cells in rats fed high-fat feed.

\section{Acknowledgment}

The researchers are grateful to Baidillah Zulkifli and Siti Prawitasari Hasibuan who had helped in the sustainability of this research.

\section{References}

1. Direktorat Jendral Hortikultura: Produksi nasional buah pisang Indonesia. http://hortikultura.deptan.go.id/. (25 Juni 2018). 2010.

2. Prabawati S, Suyanti, Setyabudi DA: Teknologi Pasca Panen dan Pengolahan Buah Pisang. Balai Besar Penelitian dan Pengembangan Pascapanen Pertanian, Bogor. 2009. 
3. Deborah N, Gemayangsura: Khasiat kulit pisang kepok (Musa acuminata) sebagai agen preventif ulkus gaster. Majority. 2015; 4(8):17-22.

4. Ranti GC, Fatimawali, Wehantouw F: Uji Efektivitas Ekstrak Flavonoid dan Steroid dari Gedi (Abelmoschus Manihot) sebagai Anti Obesitas dan Hipolipidemik pada Tikus Putih Jantan Galur Wistar. Jurnal Ilmiah Farmasi. 2013; 2(2).

5. Andini AMN: Pengaruh Pemberian Ekstrak Etanol Kulit Pisang Ambon dan Kulit Pisang Kepok Terhadap Kadar Kolesterol Total Tikus Putih Jantan Galur Sprague Dawley. Skripsi. Universitas Lampung. Bandar Lampung. 2014.

6. Yang J, Zhang X, Liu Z, et al. : High-cholesterol diet disrupts the levels of hormones derived from anterior pituitary basophilic cells. Journal of Neuroendocrinology. [Abstract]. 2016.

7. Lopes MBS: Pituitary Tumor Pathology. https://emedicine.medscape.com/article/1868045overview. (27 Desember 2017). 2015.

8. Selamet RN, Sugito, Dasrul: The effect of tomato extract (Lycorsicon esculentum on the formation of atherosclerosis in white rats (Rattus norvegicus) male. Jurnal Natural. 2013; 13(2): 5-11.

9. Novelli ELB, Diniz YS, Galhardi CM, et al. : Anthropometrical parameters and markers of obesity in rats. Laboratory Animals. 2007; 41: 111-119.

10. Malafaia AB, Nassif PAN, Ribas CAPM, et al. : Obesity induction with high fat sucrose in rats. $A B C D$ Arq Bras Cir Dig. 2013; 26: 17-21.
11. Kiernan JA: Histological and Histochemical Method: Theory and Practice. $3^{\text {rd }}$ ed. Pergamon, USA. 1993.

12. Phillips KP, Tanphaichitr N: Mechanisms of obesityinduced male infertility. Expert Rev. Endocrinol. Metab. 5(2), 229-251.

13. Bashandy AES: Effect of fixed oil Nigella sativa on male fertility in normal and hyperlipidemic rats. Intl.J. Pharmacol. 2006; 2(1): 104-109.

14. Fatemeh SR, Saifullah R, Abbas FMA, et al. : Total Phenolics, Flavonoids, and Antioxidant Activity of Banana Pulp and Peel Flours: Influence of Variety and Stage of Ripenes. Int. Food Research Journal. 2012; 19(3): 1041-1046.

15. Berawi $\mathrm{KN}$, Bimandama MA: The effect of giving extract etanol of kepok banana peel (Musa acuminata) toward total cholesterol level on male mice (Mus musculus l.) strain deutschland-denken-yoken (ddy) obese. Biomed. \& Pharmacol. J. 2018; 11(2): 769-774.

16. Kao YH, Hiipakka RA, Liao S: Modulation of Endocrine Systems and Food Intake by Green Tea Epigallocatechin Gallate. Endocrinology. 2000; 141: 980-987.

17. Zhang WL, Zhu L, Jiang JG: Active ingredients from natural botanicals in the treatment of obesity. Obes. Rev. 2014; 15: 957-967.

18. Bast A, Haenen GRMM: The toxicity of the antioxidants and their metabolites. Environ.Toxicol. Pharmacol. 2002; 11: 251-258. 